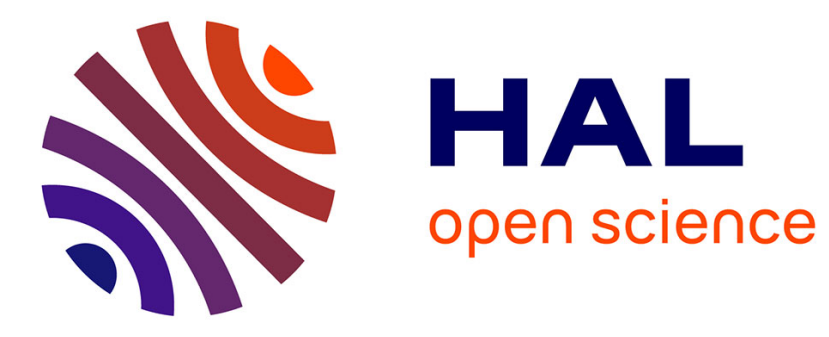

\title{
Experimental studies on the elongation of the ewe blastocyst
}

J.-E. Fléchon, M. Guillomot, Madia Charlier, Bernadette Fléchon, J. Martal

\section{To cite this version:}

J.-E. Fléchon, M. Guillomot, Madia Charlier, Bernadette Fléchon, J. Martal. Experimental studies on the elongation of the ewe blastocyst. Reproduction Nutrition Développement, 1986, 26 (4), pp.10171024. hal-00898508

\section{HAL Id: hal-00898508 https://hal.science/hal-00898508}

Submitted on 1 Jan 1986

HAL is a multi-disciplinary open access archive for the deposit and dissemination of scientific research documents, whether they are published or not. The documents may come from teaching and research institutions in France or abroad, or from public or private research centers.
L'archive ouverte pluridisciplinaire HAL, est destinée au dépôt et à la diffusion de documents scientifiques de niveau recherche, publiés ou non, émanant des établissements d'enseignement et de recherche français ou étrangers, des laboratoires publics ou privés. 
Reprod. Nutr. Dévelop., 1986, 26 (4), 1017-1024.

\title{
Experimental studies on the elongation of the ewe blastocyst
}

\author{
J.-E. FLÉCHON, M. GUILLOMOT (*), Madia CHARLIER (*), Bernadette \\ FLÉCHON, J. MARTAL $(*)$
}

Unité de Biologie du Développement.

(*) Unité d'Endocrinologie de l'Embryon.

Physiologie animale, I.N.R.A. 78350 Jouy-en-Josas, France.

Summary. After the zona is shed, the ewe blastocyst increases rapidly in diameter and length. The aim of the present study was to examine the control of trophoblast growth. Twelve-day old ovine blastocysts, cut into pieces and cultured in vitro for $24 \mathrm{~h}$, gave rise to structures called trophoblastic vesicles (blastocysts without the embryonic disc). Such trophoblastic vesicles (TV), cultured at least 5 to 10 days or more in vitro, were able to survive. However, they did not increase in length and only some of them began to form small buds. In contrast, after they were transferred surgically into the uterine horn ipsilateral to the corpus luteum on Day 12 of the oestrous cycle, these TV were elongated in 5 out of 7 recipient ewes slaughtered on Day 17.

The structure of the TV was observed by scanning electron microscopy before and after in vitro elongation and then compared with that of control blastocysts which had been cultured or not.

This study demonstrates that trophoblast elongation does not depend necessarily on the presence of the embryo proper, but can occur in TV composed only of the trophectoderm and the extraembryonic endoderm. The results also suggest that some unknown uterine factor(s) is involved in the development of trophoblastic tissue.

\section{Introduction.}

After the zona is shed on Day 8 of gestation, the ovine blastocyst undergoes rapid and spectacular elongation; from a few millimeters in length on Day 11, it increases to more than $25 \mathrm{~cm}$ on Day 17. Therefore, by Day 14 large morphological changes have taken place during the time the initially spherical blastocyst was assuming a tubular shape (Bindon, 1971). Although the regulation of trophoblast growth is probably under endocrinological uterine control, it has not been elucidated in any species (Wintenberger-Torrès, 1967 ; Short, 1969 ; Ilgren, 1981 ; Martal et al., 1985). The elongation phase of the trophoblast in sheep begins at the same time as the inhibition of cyclic luteolysis (Moor and Rowson, 1966 ; Martal, 1981). The control of these different events is one aspect of the numerous mechanisms involved in the maternal recognition of pregnancy (Bazer and First, 1983). 
In rodents, the blastocyst remains almost spherical and the proliferation of its trophectoderm depends largely on the inner cell mass (ICM) which becomes the embryo proper. In contrast, the blastocyst of ruminants and pigs elongates considerably so that the trophectoderm cells are finally located far from the cells of the embryonic disc which are liable to induce their proliferation. On Day 15 of pregnancy, the ovine trophoblast is about 50 -fold longer than the ICM. Moreover, during studies on trophoblastin (Martal et al., 1979), elongation of the trophoblastic vesicles (blastocyst fragments without the embryonic disc) was occasionally observed after transfer to the uterus of cattle or sheep (Heyman et al., 1984 ; Martal et al., 1984).

In order to study more thoroughly the factors controlling trophoblast growth, we cultured ovine trophoblastic vesicles (TV) for variable periods of time. Some of them were then transferred into the uterus of cyclic recipient ewes.

\section{Material and methods.}

Animals. - Nineteen primiparous or multiparous « Préalpes du Sud » ewes were used in this experiment.

Donor ewes. - Embryos were obtained from ewes synchronized with vaginal sponges impregnated with $30 \mathrm{mg}$ of $17 \alpha$-acetoxy-9 $\alpha$-fluoro- $11 \beta$-hydroxyprogesterone (Searle Intervet, France) (Robinson, 1965; Shelton, 1965); they were removed after 14 days and the ewes were superovulated with $14 \mathrm{mg}$ of FSH-P (Burns-Biotec, USA) per ewe. Four injections were given : 24 and $12 \mathrm{~h}$ before sponge withdrawal, during withdrawal, and $12 \mathrm{~h}$ afterwards. The ewes were mated twice on the day of oestrus (designated as Day 0). After slaughter of the donor ewes on Day 12 of pregnancy, the embryos were collected by flushing the uterine horns with phosphate buffered saline (Tervit, Whittingham and Rowson, 1972), supplemented with $2 \%(w / v)$ bovine serum albumin (fraction $V$; Sigma).

Preparation of trophoblastic vesicles. - After the 12-day old embryos had been collected, blastocysts in the early elongation stage $(0.5$ to $2 \mathrm{~mm}$ long) were used to prepare the TV. Each embryo was cut into two or three pieces to remove the embryonic disc. All of the pieces of the trophoblastic tissue were cultured for $24 \mathrm{~h}$ at $38{ }^{\circ} \mathrm{C}$ in $300 \mu$ l of $\mathrm{B} 2$ medium under an atmosphere of $20 \% \mathrm{O}_{2}, 5 \% \mathrm{CO}_{2}$ and $75 \% \mathrm{~N}_{2}$. During culture, the pieces of trophoblastic tissue formed spherical vesicles called trophoblastic vesicles.

Recipient ewes. - Seven recipient ewes, synchronized as previously described, were anaesthetized with halothane (Fluothane, I.C.I. Pharma) on Day 12 of the oestrous cycle and the corpora lutea were labelled with India ink. Two TV derived from the 12-day old blastocysts were transferred into $0.2 \mathrm{ml}$ of $\mathrm{B} 2$ medium (ApiSystem, La Balme-les-Grottes, 38390 Montalieu-Vercieu-France) into the upper third of the uterine horn ipsilateral to the corpus luteum.

Observations after transfer. - Five days after transfer, the ewes were slaughtered. The labelled corpora lutea were observed, dissected and weighed. The genital 
tracts were flushed to check for the presence of trophoblastic tissue. The length of the TV was measured.

Preparation for scanning electron microscopy. - The tissue was rinsed in phosphate-buffered saline and fixed with $1 \%$ glutaraldhyde in $0.125 \mathrm{M}$ cacodylate buffer $(\mathrm{pH} \mathrm{7.3)}$ at room temperature for at least $1 \mathrm{~h}$. The specimens were left in the fixative overnight at $4{ }^{\circ} \mathrm{C}$ and then postfixed for $1 \mathrm{~h}$ with $1 \% \mathrm{OsO}_{4}$ in cacodylate buffer $(\mathrm{pH}$ 7.3). After dehydration in ethanol, the material was critical-point dried in Freon 13 and gold-coated.

\section{Results.}

Luteal activity of recipient ewes (table 1). - As recorded in previous studies performed with a larger number of animals (Martal et al., 1979), corpus luteum weight was not statistically different on Day 12 than on Day 17 of pregnancy. There were great individual variations in corpus luteum weight in these experiments. A good correlation was noted between the functional activity of the corpus luteum and its weight (Denamur, Martinet and Short, 1973 ; Martal et al., 1979). Recipient ewes (numbers 2452, 2066 and 2456) returned to oestrous on Days 16 to 17 ; these ewes had light corpora lutea. The luteolysis of ewe $\mathrm{N}^{\circ} 2060$ seemed delayed, considering luteal weight. This may have been due to abundant secretion of trophoblastin (Martal et al., 1979) on Day 12, even though there was no trophoblast elongation. The ewes exhibiting more pronounced elongation of the TV after transfer either had several corpora lutea weighing about $400 \mathrm{mg}$ (ewe $N^{\circ} 2432$ ), or only one of three was well developed (ewe $N^{\circ} 2419$ ) (table 1 ).

TABLE 1

Weight of the corpora lutea and elongation of TV $\left(^{*}\right)$ 5 days after uterine transfer.

\begin{tabular}{ccc}
\hline & \multicolumn{1}{c}{$\begin{array}{c}\text { Weight of labelled } \\
\text { corpora lutea } \\
(\mathrm{mg})\end{array}$} & $\begin{array}{c}\text { Trophoblast length } \\
(\mathrm{mm})\end{array}$ \\
\cline { 2 - 3 } $\begin{array}{c}\text { Pregnant donor ewes } \\
\text { (n = 10) }\end{array}$ & $625 \pm 75$ & $0.5-2$ \\
\hline Recipient ewes $\left(^{* *}\right)$ & 325 & disappeared \\
2452 & $610-634$ & 2 \\
2060 & $207-238$ & 10 \\
2066 & $317-278$ & 17 \\
2456 & $457-325$ & 117 \\
2096 & $380-410-379$ & 182 \\
2432 & $195-247-540$ & $>250$ \\
2419 & & $>250$ \\
\hline 2028 & 586 & \\
\hline Pregnant control ewes & $400-444$ & \\
\hline
\end{tabular}

$\left(^{*}\right)$ TV: ovine trophoblastic vesicles from 12-day-old blastocysts.

$\left(^{*}\right)$ Two TV were transferred per recipient ewe on Day 12 of the oestrous cycle. 
Elongation of trophoblastic vesicles. - After $24 \mathrm{~h}$ of culture in B2 medium enriched with bovine serum albumin, most pieces of trophoblastic tissue became spherical and exhibited a prominent scar composed of larger cells. Some of the TV also produced small buds that divided into little vesicles a few days later. Whatever the length of culture time (up to 20 days), the TV never elongated in vitro under our experimental conditions. After 10 to 20 days of culture, they either shrank, turned dark and died, or swelled and burst into fragments. After transfer into the uterine horn, several TV elongated markedly. Some of them lengthened 5 to 10 (ewes $\mathrm{N}^{\circ} 2066,2456$ and 1096) or even 100 (ewes $\mathrm{N}^{\circ} 2432,2419$ )-fold from the day of transfer (table 1).

Scanning electron microscopy. - As shown in PI. 1 (fig. a), normal 12-day old blastocysts measured 1 to $2 \mathrm{~mm}$ in diameter and were not elongated. They were completely covered by the trophoblastic epithelium (trophectoderm), except for the embryonic disc which was composed of embryonic ectoderm. After one day of culture, the TV appeared spherical and were covered by the trophoblastic epithelium (Plate 1, fig. c). Cell blebs and extrusions were visible, particularly on the scars which developed at the site of section. When whole 12-day old blastocysts were cultured in the same conditions, extruded cells were also visible (PI. 1, fig. b), but in smaller numbers. When TV were cultured in vitro for 5 days or more (13 days in PI. 1, fig. d), they survived but never elongated; their appearance was similar to that of TV cultured for only one day (PI. 1, fig. c). Elongation occurred only when the TV's were transferred in vivo as shown in Plate 1 (fig. f). However, the increase in length and diameter never matched that of control blastocysts (PI. 1, fig. e). The trophectoderm cells exhibited the same heterogeneous aspect on the globular and newly-developed tubular part of the TV.

\section{Discussion.}

The trophoblastic epithelium of 12-day old sheep embryos, cultured in vitro, maintained a normal appearance, as shown by scanning electron microscopy, although the size of the trophoblastic cells was particularly irregular around the

FIG. a. - 12-day old control blastocyst. The embryonic disc is pushing through an opening in the trophectoderm. $\times 30$.

FIG. b. - 12-day old blastocyst after 24-hour culture. Many trophoblast cells or cytoplasmic blebs are being extruded. The embryonic disc is seen at the upper right. $\times 100$.

FIG. c. - 12-day old trophoblastic vesicle after 24-hour culture. Extruding trophoblast cells or cytoplasmic blebs are frequent, particularly along the scar. $\times 160$.

FIG. d. - 12-day old trophoblastic vesicle after 13-day culture. Very similar aspect with extruding cells around the scar. $\times 160$.

FIG. e. - 14-day old control blastocyst with the embryonic disc $(-1 . \times 25$.

FIG. f. - Elongated 12-day old trophoblastic vesicle 5 days after transfer into a recipient ewe. The original round vesicle is seen at the lower right. $\times 40$. 

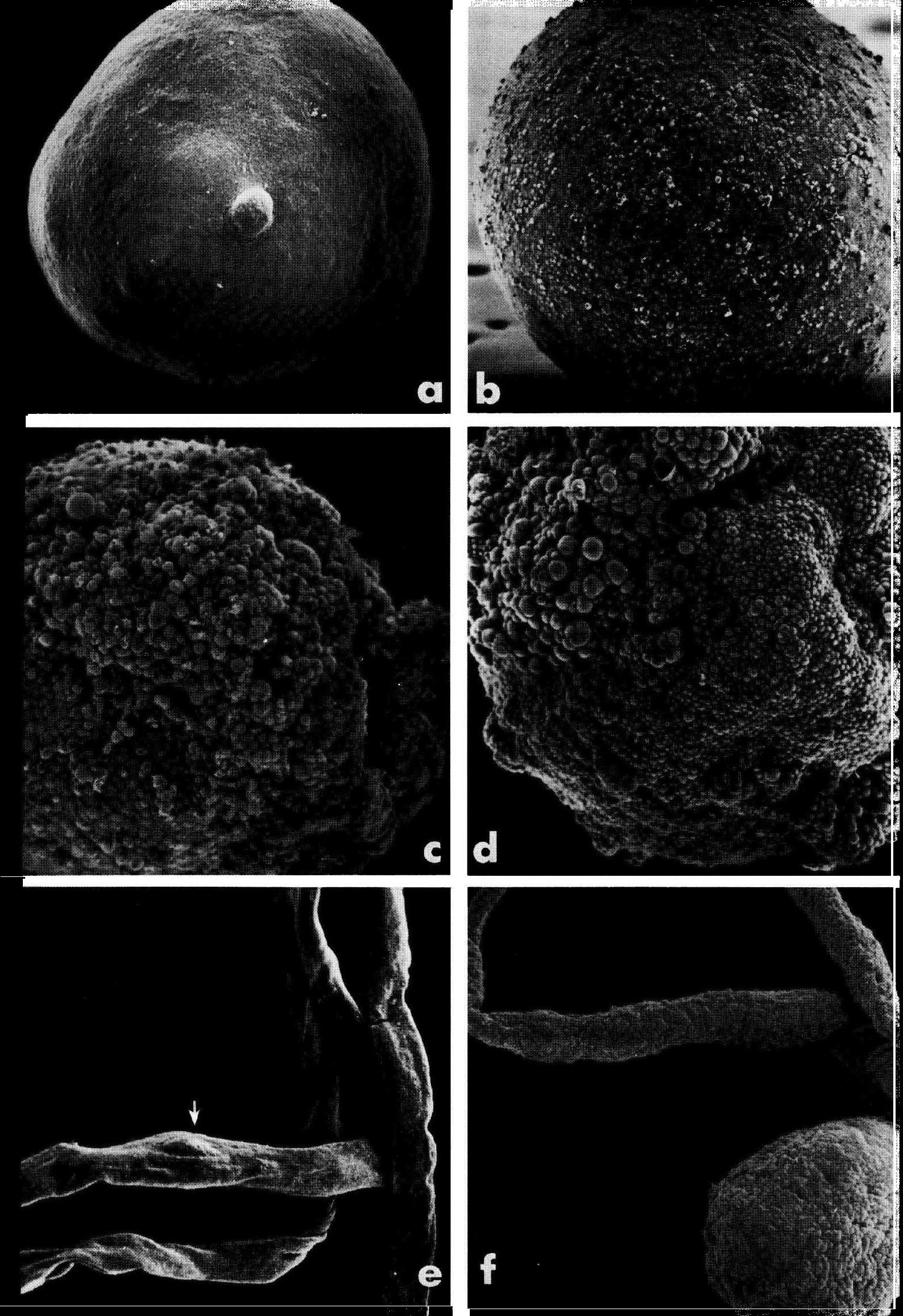
scar. However, the shape of these TV did not change during culture. On the contrary, TV derived from 12-day old blastocysts, transferred in vivo, elongated after 5 days (up to $182 \mathrm{~mm}$ ) and were no longer spherical. This increase in length was less than that of 17-day old ovine blastocysts which measured more than $250 \mathrm{~mm}$. The trophectoderm cells of elongated vesicles analysed by scanning electron microscopy had an aspect similar to that of normal blastocysts at the same age. Moreover, the luteal weight of recipient ewes was comparable to that of control ewes on Day 17 of pregnancy.

After transfer, the TV survived in utero during the period of maternal recognition of pregnancy which results in luteal maintenance. According to Martal (1981), this period lasts about 10 days in ewes (Day 12 to Day 22). The importance of local embryonic action (Moor and Rowson, 1966) and the effects of small amounts of transferred trophoblastic tissue (2 ovine TV per recipient ewe : Heyman et al., 1984) indicate that this material has an intense secretory activity and a high growth potential.

These results also suggest that the presence of the embryonic disc is not essential to blastocyst elongation, although it may be necessary for the long-term survival of trophoblastic tissue. Besides, the uterus seems to play an important role in the secretion of one or several factors inducing elongation. These factors have not been identified. Our results, like those of Lawson, Parr and Cahill (1983), suggest uterine control of blastocyst growth.

Considering the aspect of the cells from TV elongated in vivo, trophoblast growth does not seem to result from hypertrophy but rather from cell multiplication (unpublished data). In contrast, the spectacular blastocysts elongation in sows would not be characterized by an increase in trophoblast DNA content. At least, cell hyperplasia would not be involved in the initial elongation of the porcine blastocyst (Geisert et al., 1982).

A protein of about 21000 to 27000 daltons, capable of stimulating DNA synthesis in cultured cells, has been isolated from the endometrium of pregnant and non-pregnant sows. This protein inhibiting the epidermal growth factor (EGF) binding to endometrial receptors, is not specific to the endometrium since it is also present in other tissues (Brigstock et al., 1983). The molecular weight of the EGF is different, being about 6000 daltons (Carpenter and Cohen, 1979). Moreover, polypeptides have been reported in the uterine secretion of many species, including ruminants (Ménézo and Wintenberger-Torrès, 1976; Bazer et al., 1981) ; some of these polypeptides could be involved in embryo growth in vivo.

Further studies are required to determine the exact role of the embryonic disc or inner cell mass (ICM) in elongation since the in vivo elongation of TV is less than in the control blastocysts. Studies must be also done on the interaction of the trophectoderm and the endoderm derived from the ICM. 


\section{Rósumé. Etudes expérimentales de l'allongement du trophoblaste chez la brebis.}

Après sa sortie de la zone pellucide, le blastocyste de brebis augmente rapidement de diamètre et de longueur. Les expériences suivantes ont été effectuées pour étudier le contrôle de la croissance du trophoblaste. Des blastocystes ovins, âgés de 12 jours, découpés puis cultivés pendant $24 \mathrm{~h}$, donnent naissance à des structures appelées vésicules trophoblastiques IVT, blastocyste dépourvu de disque embryonnaire). Ces VT, cultivées pendant au moins 5 à 10 jours, sont capables de survivre ; néanmoins, elles ne grandissent pas en longueur et seulement quelques-unes d'entre elles bourgeonnent de petites vésicules. Au contraire, après transplantation chirurgicale dans la corne utérine adjacente au corps jaune de brebis receveuses, au $12^{\circ}$ jour du cycle œstrien, des VT s'allongent chez 5 sur 7 des brebis, abattues au $17^{\mathrm{e}}$ jour après l'œstrus. La structure des vésicules trophoblastiques est observée au microscope à balayage avant et après allongement in vivo et est comparée à celle des blastocystes témoins, cultivés ou non.

Ces expériences démontrent que l'allongement du trophoblaste a lieu indépendamment de la présence de l'embryon proprement dit, quoique en présence de l'endoderme extraembryonnaire. Ces résultats suggèrent aussi qu'un ou plusieurs facteurs utérins encore inconnus sont impliqués dans le développement du tissu trophoblastique.

\section{References}

BAZER F. W., FIRST N. L., 1983. Pregnancy and parturition. J. anim. Sci., 57 (suppl. 2), 425-460.

BAZER F. W., ROBERTS R. M., SHARP D. C., THATCHER W. W., 1981. Uterine proteins synthetized during the progestative period and pregnancy, 17-32. In BOURY-HEYLER C., MAULEON P. \& ROCHET Y., Uterus et Fécondité. Masson Paris.

BINDON B. M., 1971. Systematic study of preimplantation stages of pregnancy in the sheep. Aust. J. biol. Sci., 24, 131-147.

BRIGSTOCK D. R., BROWN K. O., HEAP R. B., LAURIE M. S., 1983. Cell growth-promoting polypeptides in the uterus of the pig. J. Physiol., 343, 126P.

CARPENTER G., COHEN S., 1979. Epidermal growth factor. Ann. Rev. Biochem., 48, $193-216$.

DENAMUR R., MARTINET J., SHORT R. V., 1973. Pituitary control of the ovine corpus luteum. J. Reprod. Fert., 32, 207-220.

GEISERT R. D., THATCHER W. W., ROBERTS R. M., BAZER F. W., 1982. Establishment of pregnancy in the pig. II. Cellular remodeling of the porcine blastocyst during elongation on day 12 of pregnancy. Biol. Reprod., 27, 941-955.

HEYMAN Y., CAMOUS S., FĖVRE J., MEZIOU W., MARTAL J., 1984. Maintenance of corpus luteum after uterine transfer of trophoblastic vesicles in cyclic cows and ewes. J. Reprod. Fert., 70, 533-540.

ILGREN E. B., 1981. On the control of the trophoblastic giant-cell transformation in the mouse : homotypic cellular interactions and polyploidy. J. Embryol. exp. Morph., 62, 183-202.

LAWSON R. A. S., PARR R. A., CAHILL L. P., 1983. Evidence for maternal control of blastocyst growth after asynchronous transfer of embryos to the uterus of the ewe. J. Reprod. Fert., 67, 477-483.

MARTAL J., 1981. Control of luteal function during early pregnancy in sheep. J. Reprod. Fert., suppl. 30, 201-210

MARTAL J., CAMOUS S., FĖVRE J., CHARLIER M., HEYMAN Y., 1984. Specificity of embryonic signals maintaining corpus luteum in early pregnancy in ruminants, 512-514. Proc. 10th int. Congr, on Animal Reproduction and A.I., Urbana-Champaign, Illinois, USA. Brief communications.

MARTAL J., CHARLIER M., CHÊNE N., CHARPIGNY G., CAMOUS S., GUILLOMOT M., 1985. Signaux embryonnaires et environnement utérin au cours de la progestation chez les Ruminants, 245-270. In ESPINASSE J., Mieux connaître, comprendre et maîtriser la fécondité bovine, Sté française de Buiatrie, E.N.V.A. Maisons-Alfort. 
MARTAL J., LACROIX M. C., LOUDES C., SAUNIER M., WINTENBERGER-TORRĖS S., 1979. Trophoblastin, an antiluteolytic protein present in early pregnancy in sheep. J. Reprod. Fert., 56, 63-73.

MÉNÉZO Y., 1976. Milieu synthétique pour la survie et la maturation des gamètes et pour la culture de I'œu fécondé. C. R. Acad. Sci. Paris, sér. D, 282, 1967-1970.

MÉNÉZO Y., WINTENBERGER-TORRĖS S., 1976. Free amino acid content of ewe uterine fluid under various hormonal treatments during early pregnancy. Ann. Biol. anim. Bioch. Biophys., 16, 537-543.

MOOR R. M., ROWSON L. E. A., 1966. The corpus luteum of the sheep : functional relationship between the embryo and corpus luteum. J. Endocr., 34, 223-239.

ROBINSON T. J., 1965. Use of progestagen-impregnated sponges inserted intravaginally or subcutaneously for the control of the oestrous cycle in the sheep. Nature, London, 206, 39-41.

ROWSON L. E. A., LAWSON R. A. S., MOOR R. M., BAKER A. A., 1972. Egg transfer in the cow : synchronization requirements. J. Reprod. Fert., 28, 427-431.

SHELTON J. N., 1965. Identification of progesterone of high activity for the control of the oestrous cycle in the sheep. Nature, London, 206, 156-158.

SHORT R. V., 1969. Implantation and the maternal recognition of pregnancy. pp. 2-26. In Foetal autonomy. CIBA Found. Symp., Churchill Livingstone, London.

TERVIT H. R., WHITTINGHAM D. G., ROWSON L. E. A., 1972. Successful culture in vitro of sheep and cattle ova. J. Reprod. Fert., 30, 493-497.

WINTENBERGER-TORRĖS S., 1967. Action de la progestérone et des stéroïdes ovariens sur la segmentation des ceufs chez la Brebis. Ann. Biol. anim. Bioch. Biophys., 7, 391-406. 